\title{
Nouveau Roman and Postmodernism
}

\author{
Dai Hongbin \\ Xiamen University, Xiamen, China \\ dhb9608@163.com
}

Keywords: Nouveau Roman, postmodernism, relation

\begin{abstract}
Nouveau Roman plays an important role in the era of postmodern writings. It is considered to be an innovative school of writing, which demonstrates a good variety of postmodernist features. The new novelists display some measure of dissatisfaction with the previous textual practice, especially with the common practice of coherent narrative. Their works have special treatment of language. Usually there is loss of meanings and the dissolution of the depth pattern in the novels.
\end{abstract}

\section{Introduction}

As a French term, "Nouveau roman" is, according to Chris Baldick, "applied since the mid1950s to experimental novels by a group of French writers who rejected many of the traditional elements of novel-writing such as the sequential plot and the analysis of characters' motives." [1] The leading light of the group, Alain Robbe-Grillet, in his Pour un Nouveau Roman (1963), argues for a neutral register of sensations and things. It is generally agreed that the first probable prototype of the nouveau roman is Tropismes published by Nathalie Sarraute in 1939. However, people do not reach a consensus as to the exact date of the first deliberate use of "the nouveau roman" as the term to name what seems to be a new literary group or movement. J. A. Cuddon writes that it "appears to have become part of critical jargon in France in 1955 with the publication (in periodicals and reviews) of Robbe-Grillet's essays on the nature and future of the novel."[2] Its first use may have been, "as Jean-Pierre Faye suggests, by Maurice Nadeau in an article written in 1957."[3] Nevertheless, it is certain that the phenomenon and development of the nouveau roman were confirmed in the special issue of the review Esprit published in August 1958.[4]The core of the body of works described by the issue as the "nouveau roman" contains: Alain Robbe-Grillet's Les Gommes (1953), Le Voyeur (1955) and La Jalousie (1957), Nathalie Sarraute's Martereau (1954) and L'Ere du Soupçon (1956), Michel Butor's L'Emploi du Temps (1956) and La Modification (1957), Claude Simon's L'Herbe, etc. Accordingly, it is in the fifties that the idea of the nouveau roman was formulated as well as developed. At that time, the key novels and theoretical writings were written and people came to recognize the nouveau roman as a movement and accept the fact that the nouveau roman dominated the French literary scene of that period. In the history of the nouveau roman, Alain Robbe-Grillet is a prominent and most influential figure whose works and theoretical writings help to define and discuss the movement, the phenomenon and the significance of the nouveau roman. Spark has more than once admitted her indebtness to him. Robbe-Grillet's theories were later gathered in Pour un Nouveau Roman (1963) which serves as a guidance to the general writing techniques of the nouveau roman.

The nature and the novelty of the nouveau roman vary according to different critics. One hostile 
view is caused by the severe reduction in the range of what is represented by the nouveau roman. Balzac and Gide tend to have a sizable panorama in their novels. By contrast, the nouveau roman appears to be extremely emaciated; What's more, representation of the novels at times seems unrealistic or inaccurate, as the readers of Robbe-Grillet complain: "Things don't happen like that in real life,' 'A jealousy husband doesn't behave like the one in your Jalousie'.'[5]Consequently, the insubstantiality of the contents of the nouveau roman prevents it from being regarded as fiction for it seems to be in lack of a serious realist purpose, thus making the nouveau roman unwelcome.

\section{The Nature of Nouveau Roman}

One view about the novelty and nature of the nouveau roman contends that it is "a part of a developing tradition in twentieth-century fiction whereby the burden of realism is gradually shifted from content to form (and thus renders the form-content distinction redundant)."[6] This view can be named that of formal realism and there exist two different kinds of interpretations as to the nature of this formal realism: one which assumes that the formal organization of the novel mirrors the organization of the society in which it is produced; another which holds that it mirrors the structure and patterns of human consciousness. [7] The view of formal realism is rational due to its ability to account for the change in the fiction in terms of historical factors. Nevertheless, it has the disadvantage that it defines the novel only by external issues like the economic structure of the society and the nature of human experience, rather than by the genre of novel itself.

Another view represented by Ricardou defines it in accordance to its opposition to traditional fiction. Ricardou's interests in the nouveau roman lie in two aspects: the way in which realist conventions are contested, and the structural development of the strictly formal features of the writing. He believes that the nouveau roman attempts to overturn the conventions which imply that the novel is a copy of reality and the nouveau roman is constituted instead primarily by writing itself, which produces instead of copying reality.[8]

Besides the nature of the nouveau roman, the most often discussed factors concern the plot and the character, the innovative handling of which is the most conspicuous feature of the nouveau roman. Robbe-Grillet has a low opinion of the plot. He argues that the order and coherence of the plot tend to provide a false view of the world as ordered and intelligible. Also, he believes that the plot is not confident or coherent as before, and things happen, but the relation between them is seen to be problematic. [9] Nathalie Sarraute also talks about plot with a scornful tone. Plot is an artificial form of representation that "by wrapping itself around the character like a bandage, creates an impression of coherence and life, but also gives him the rigidity of a mummy."[10]

In addition to the issue of the plot, Grillet, Sarraute and Ann Jefferson make some enlightening comments on that of the character. Because of the attack made by Robbe-Grillet and Nathalie Sarraute on it, the character seems to be abolished in the novel, which leads to the elimination of the human factors from the novel. However, the truth is that despite his fierce attack on character, Robbe-Grillet contends that the description of character is only reduced in the novel and the reduction is determined by social changes in the world that we live in:

The character novel belongs well and truly to the past, it typifies a certain era; when the individual were at his height. Perhaps it is not a sign of progress, but we are now in the age of the regimental number. For us, the fate of the world is no longer related to the rise and fall of a few men or a few families... To have a name was doubtless very important in the days of the Balzacian bourgeoisie. A character was all the more important as it was also a weapon in any confrontation...[11]

He then describes the status of human beings in the nouveau roman as one of anonymity. It seems that Spark learns from Grillet to design Lise's near anonymity in her The Driver's Seat. In 
another essay, Robbe-Grillet argues that the abolition of the conventional character does not lead to the disappearance of human elements in the novel:

As there were no "characters" in our books, in the traditional sense of the word, people somewhat hastily concluded that there were no people in them at all. This was a serious misreading of them. Man is present on every page, in every line, in every word. [12]

In short, Robbe-Grillet argues that there are human beings in his fiction which assume the form of anonymity and point of view instead of individuality and objective representation of the traditional novel.

Nathalie Sarraute's viewpoints on character are similar to Robbe-Grillet's. She argues that the existence of Balzacian characters in modern fiction will lead to a mutual distrust between the author and the reader, therefore externally portrayed characters have no place in modern fiction in which there are anonymous characters:

Nowadays, we are being inundated by an ever-increasing flood of literary works which still claim to be novels and where an indefinable, elusive and invisible creature with no sharp outline, an anonymous I, who is everything and nothing, and who is usually just a reflection of the author, has usurped the role of the main hero and taken the place of honour. The characters around him, with no existence of their own, are no more than the perceptions, dreams, nightmares, illusions, reflections, modalities or dependencies of this all-powerful I. [13]

As a result, the invisibility and the anonymity are the marks of a protagonist whose particular points of view reflect the world and the people around him.

Both Sarraute and Robbe-Grillet notice the changes in character, but they interpret the changes in different ways: while Robbe-Grillet finds reasons in the change of status of individuals in modern society, Sarraute justifies the changes from the psychological perspective. She claims that our interest in human beings has changed since the first half of the nineteenth century, and we have gone beyond a preoccupation with personality to a deeper level of psychological reality. [14]

However, Ann Jefferson claims that the nouveau roman has effaced the realistic effect which the concept of character has made available in the past. According to her, the nouveau roman makes three contributions to poetics of character in the novel: firstly, it shows us that the coherence provided by character is illusory because it rests on a certain kind of discourse which the nouveau roman treats as platitude or mask; secondly, it shows us that the lifelikeness of character highly valued in the past is the effect of certain rhetorical strategies; lastly, through the treatment of characters as speakers, it opens up the possibility of seeing a whole discursive polyphony in fiction, where the issue at stake has more to do with the nature of the languages that we use for the representation than to do with the adequacy of the novel's representation of character as mind or social entity.[15]

The nouveau roman is closely connected with the term postmodernism, as Edmund Smyth writes in "The Nouveau Roman: Modernity and Postmodernity":

It would not be an exaggeration to stress the extent to which the nouveau roman has dictated the terms of critical discourse, nor to state that it still acts as the essential reference point in any definition of postmodern aesthetics. The sustained and systematic assault upon the assumptions and procedures of classic realism, vigorously pursued by the leading nouveaux romanciers, could almost be said to represent a manifesto of postmodern aims and aspirations...[16]

\section{The Relationship between the Nouveau Roman and Postmodernism}

Since the relationship between the nouveau roman and postmodernism is so intimate, what are the postmodernist characteristics of the nouveau roman? As the works of the new novelists show, they demonstrate some measure of dissatisfaction with the previous textual practice, especially with 
the common practice of coherent narrative. Hence, there is the tendency that nothing of the coherent narrative perspective exists in the nouveau roman, which can be regarded as one important feature of postmodernism. Spark grasps the significance of the tendency and rejects the sequential plot in The Driver's Seat, which reveals her influence by the Nouveau Roman.

The next major postmodernist characteristic of the nouveau roman lies in its special treatment of language. "For a text to be described as a nouveau roman it had to exhibit self-reflexive and metafictional features as well as foreground the exploration of the semantic and phonetic properties of language."[17] Ricardou, the prominent critic who contributes a lot to the poetics of the nouveau roman, proclaims that the nouveau roman is in favor of the free play of the signifier at the expense of the signified, and he stresses the importance of word-play and the exploration of the properties of language in the elaboration of the text. According to him, the materiality of the text should replace the evocation of the workings of consciousness.[18]

Another postmodernist characteristic of the nouveau roman is the loss of meanings and the dissolution of the depth pattern in the novels. The loss of depth reflects the loss of the traditional value and shows that literature puts its original obligation and tasks to doubt and negates the present order, authority, criteria, and so on. Thus, the world in the fiction often reveals the features of instability, plurality, ignobility, fragmentation, elusiveness, indeterminacy, and inexpressiveness. To dissolve the depth pattern, new novelists usually choose seemingly insignificant and valueless topics and make full use of the device of collage to make up the whole story. It is through the use of the technique of collage that writers disregard the conventional concepts of space and time, subvert the causal logic, and put together the largely unconnected objects with respect to either time or space. They may juxtapose fragments in their consciousness or memory at random to construct their fictional world and express their views. The other form of the loss of the depth pattern involves the elimination of psychological perspectives in the nouveau roman. Again, Spark's purposeful refusal to provide any information of the characters' psychological state in her The Driver's Seat confirms her benefits from the nouveau roman. Writers are inclined to discard the descriptions of the characters' mental or spiritual state which is highly valued as an important aspect of traditional and modern writings. Without the descriptions of the mental state of characters, the novel appears to be lacking in depth, which is paradigmatic of postmodernist writings, and only makes itself interpreted through the impersonal and objective descriptions of the outer appearances of things. This leads to the loss of the subjective consciousness which is the main object of the modernist writers. The loss causes the human-centered point of view to be overturned and produces the subjective fragments which are characteristic of postmodernist writings.

One more postmodernist characteristic of the nouveau roman is the varied strategies it takes advantage of, as is written: "Parody, self-quotation, the mixing of writings and culturally defamiliarizing strategies place the nouveau roman firmly within postmodernism." [19] One of the most conspicuous techniques wielded by the new novelists is the mixing of a variety of writings and even the combination of the other genres with fiction. The techniques of the other arts as varied as music, films, drawings, and architecture are made use of in the writings of the nouveau roman. All these show the effects of the other art forms help the new novelists to convey their understandings of the world in fiction, and thus extend the range of fiction. As a result, Smyth argues that "the pluralizing nature of texts as varied as Robbe-Grillet's Le Miroir Qui Revient and La Maison de Rendez-vous, Claude Simon's ... places them firmly within the postmodernist camp.’[20]

In summary, the nouveau roman is an innovative school of literature whose major concerns involve the perspectives of the character description and the plot design. The nouveau roman places itself in the camp of postmodernism, owing to its incoherent narrative perspectives, its uncommon handling of language, its dissolution of the depth pattern, and the mixing of varied strategies in the novel. 


\section{References}

[1] Chris Baldick, Oxford Concise Dictionary of Literary Terms (Oxford: Oxford University Press, 2000) 151.

[2] J. A. Cuddon, ed, A Dictionary of Literary Terms (New York: Penguin, 1986) 428.

[3] Cf. Stephen Heath, The Nouveau Roman: A Study in the Practice of Writing (Philadelphia: Temple University Press, 1972) 41.

[4] It refers to "Le Nouveau Roman," Esprit 7/8 (July/August 1958).

[5] Alain Robbe-Grillet, Towards a New Novel, Trans. Barbara Wright (London: John Calder, 1970) 69.

[6] Ann Jefferson, The Nouveau Roman and the Poetics of Fiction (Cambridge: Cambridge University Press, 1980) 3.

[7] Ibid. 3.

[8] Cf. Ann Jefferson, The Nouveau Roman and the Poetics of Fiction (Cambridge: Cambridge University Press, 1980) 4.

[9] John Sturrock, The French New Novel (London: Oxford University Press, 1969) 9.

[10] Nathalie Sarraute, Tropisms and the Age of Suspicion, trans. Maria Jolas (London: John Calder, 1963) 65.

[11] Alain Robbe-Grillet, Towards a New Novel, trans. Barbara Wright (London: John Calder, 1970) 28.

[12] Ibid. 116.

[13] Nathalie Sarraute 58.

[14] Ann Jefferson 60.

[15] Ibid. 107

[16] Edmund J. Smyth, "The Nouveau Roman: Modernity and Postmodernity," Postmodernism and Contemporary Fiction, ed. Edmund J. Smyth (London: Batsford Ltd., 1991) 54.

[17] Ibid. 68.

[18] Ibid. 66.

[19] Ibid. 73.

[20] Ibid. 73. 